\title{
Ssciendo
}

Ethics \& Bioethics (in Central Europe), 2020, 10 (1-2), 69-77

DOI:10.2478/ebce-2020-0001

\section{The ethical dimension of erotic self-education and development ethics ${ }^{1}$}

\author{
Grzegorz Grzybek² \& Liliya Morska ${ }^{3}$
}

\begin{abstract}
The ethical dimension of sexual education can referred to morality, religion and the ethos of life. Morality and religion exert pressure on certain behavior patterns. "Ethical eroticism" in relation to the theory of Development ethics implies a positive integration of sexuality with the ethos of life. "Ethical eroticism" in this area is not identical to sexual morality. Sexual morality is an external element as comprehended by a person, while "ethical eroticism" based on the ethos of life expresses a person's moral subjectivity. In the principles of development ethics, the emphasis is shifted to individual development, which is the reason for propounding the postulate of erotic self-education.
\end{abstract}

Keywords: morality, sexual education, ethical eroticism, Development ethics

\section{Introduction}

The aim of the article is to reveal the ethical dimension of sexual education. The first subchapter will present moral aspects of sexuality, or rather, the interest in sex taken by "morality". The second subchapter will suggest selected ethical views on sexuality that had or still have some impact on sexual education. The last subchapter refers to the theory of Development ethics; Development ethics is "a theory which aims to show the normative dimension of human development with basic assumptions built on the theses of moral existence of the man and ethical personality" (Grzybek, 2010, p. 120). Based on this proposition, an attempt will be made to define ethical eroticism as a proposition for sexual self-education.

\section{Sex and morality}

It is worth asking the key question: why is "morality" interested in sex? What are the reasons for such an interest? Are they natural? Or, is it rather the result of a desire to effectively control faithful people (in terms of religion), subjected citizens (when it comes to some historical restrictions) in order to influence their civic behaviour and attitudes, to control business so that the customer chooses proper products?

To illustrate this issue, a few interesting statements will be provided. Quite significant in this respect is Peter Singer's view:

"So the first thing to say about ethics is that it is not a set of prohibitions particularly concerned with sex. Even in the era of AIDS, sex raises no unique moral issues at all. Decisions about sex may involve considerations of honesty, concern for others, prudence, and so on, but there is nothing special about sex in this respect, for the same could be said of decisions about driving a car" (Singer, 1999, p. 2).

The conviction that ethics should not deal with the sexual sphere has a double meaning. The first one concerns morality, that is, one should not unnecessarily moralize sexual life and burden it with prohibitions. The second meaning concerns the way of understanding ethical reflection

\footnotetext{
${ }^{1}$ The paper was presented at the international conference Global Bioethics held in Prešov (Slovakia) on 16-17 October 2019.

${ }^{2}$ University of Rzeszow, Faculty of Pedagogy, Rzeszow (Poland); ggwil@o2.pl

${ }^{3}$ University of Bielsko-Biala, Faculty of Foreign Languages, Bielsko-Biala (Poland) \& Ivan Franko National University of Lviv, Lviv (Ukraine); liliya.morska@gmail.com
} 
and the role of ethics in a person's life. If the role typical of the theory of Development ethics is accepted, then it is shaping our ethical standards - the sexual sphere then requires certain integration with the ethos of life (Grzybek, 2014, pp. 71-84). Thus, the morality present in the form of social pressure can be considered undesirable, and ethics will then be understood as life wisdom necessary for the sexual sphere (Grzybek, 2016, p. 18). Here, one can agree with Osho's view that:
"There is no future of any morality concerning sex. In fact, the very combination of sex and morality has poisoned the whole past of morality. Morality became so sex-oriented that it lost all other dimensions which are far more important. Sex should not be so much of a concern for moral thinking" (Osho, 2003, p. 131).

Morality, seen as a force exerting pressure to behave in a certain way, may be considered as a restriction of freedom, while in the sexual sphere there has been and continues to be a tendency to enslave another. Michel Foucault puts it this way:

\begin{abstract}
"The notion of repressed sex is not, therefore, only a theoretical matter. The affirmation of a sexuality that has never been more rigorously subjugated than during the age of the hypocritical, bustling, and the responsible bourgeoisie is coupled with the grandiloquence of a discourse purporting to reveal the truth about sex, modify its economy within reality, subvert the law that governs it, and change its future. The statement of oppression and the form of the sermon refer back to one another; they are mutually reinforcing. To say that sex is not repressed, or rather that the relationship between sex and power is not characterized by repression, is to risk falling into a sterile paradox. It not only runs counter to a well-accepted argument, it goes against the whole economy and all the discursive "interests" that underlie this argument" (Foucault, 1978, p. 8).
\end{abstract}

Although some oppressive approach to the sexual sphere seems to be historically determined, there is still a discussion going on and the gender struggle continues (Fromm, 1999).

Not only did Peter Singer draw attention to excessive interest in sexuality shown by religion, but Osho also emphasized the following: "All the religions are against sex because that is the only way to make you miserable. That is the only way to make you feel guilty. That is the only way to reduce you to being sinners" (Osho, 2003, p. 133). Perhaps the source of motivation of the oppressive approach to the sexual sphere is to make people unhappy so that to make them easier to be ruled. Zygmunt Bauman calls this approach the management of anxiety (Bauman, 2006; Bauman, 2010, pp. 56-57).

It is worth pointing out, however, that normalizing the sexual sphere is natural if the view of Georges Bataille is accepted:

"From the human perspective, the place of sex life is undoubtedly defined by prohibition. It is never absolutely free; the ban keeps it always within the limits set by the custom. Of course, it would be barren to resist this, against prohibition; it is not "human" to say that only freedom is compatible "with nature". Man is fundamentally different from nature, can even be viewed in strong opposition to it, and cancelling the prohibition would mean only one issue - the so-called "animality" from which people evolved (of which they are aware) and which can no longer be longed for" (Bataille, 2008, p. 22).

Since normalizing the sexual sphere seems natural, the question should be posed about the relation not only of morality to the sexual sphere, but also to ethical thought. 
The above-mentioned author in his work "History of eroticism" accepts as the starting principle that sexuality will be considered "only in concrete, coherent "wholeness' in which the erotic and intellectual world complement each other and occupy equal positions" (Bataille, 2008 , p. 22). Thus, we have sexuality subjected to morality, eroticism escaping intellectual understanding, although the thought triggers eroticism, and then eroticism triggers back the thought, as well as ethics and life ethos which should enclose sexuality.

An important problem also affecting sexuality is the awareness of sin, evil. Michel Foucault points out the right of asking the question:

\begin{abstract}
"why sex was associated with sin for such a long time-although it would remain to be discovered how this association was formed, and one would have to be careful not to state in a summary and hasty fashion that sex was "condemned" - but we must also ask why we burden ourselves today with so much guilt for having once made sex a sin. What paths have brought us to the point where we are "at fault" concerning our sex? And how have we come to be a civilization so peculiar as to tell itself that, through an abuse of power which has not ended, it has long "sinned" against sex? How does one account for the displacement which, while claiming to free us from the sinful nature of sex, taxes us with a great historical wrong which consists precisely in imagining that nature to be blameworthy and in drawing disastrous consequences from that belief' (Foucault, 1978, p. 9).
\end{abstract}

Is it possible to talk about freeing oneself from the awareness of sin in the sexual sphere? Aren't many people made to visit a psychotherapist for this reason? Maybe it is time to take heed in Osho's statements: "The future will know a different vision of sex. It will be more fun, more joy, more friendship; more a play than a serious affair as it has been in the past. It has destroyed people's lives, has burdened them so much - unnecessarily! It has created so much jealousy, possessiveness, domination, nagging, quarreling, fighting, condemnation - for no reason at all" (Osho, 2003, p. 132). It seems that due to human well-meaning, associating guilt with sexuality leads to a lack of comfort in life.

Miroslav Plzák draws attention to the problem of the moralization of the sexual sphere and the glorification of continence:

\begin{abstract}
"The general public, for example, refuses to accept the view that in just sporadic cases the subject is erotically stimulated throughout life only by one partner. Recognition of this sad fact would lead to the breakdown of the monogamous marriage model if there were no morality glorifying virtue and chastity. Most people maintain the view that women have to guard chastity rather than develop sexual and erotic techniques. The contradiction between the moral principle and the tendency of sex drive is solved in favor of the moral principle because, otherwise, it would require the necessity to reevaluate the assumptions laying the background of today's marriage and family" (Plzák, 1973, pp. 21-22).
\end{abstract}

Does the adoption of a certain model of conjugal relationships not lead to moral double standards? According to Miroslav Plzák, "The presented contradiction is, however, the cause of harmful social phenomena, such as sexual infidelity and prostitution on the one hand, and neurosis - on the other. Society reconciles this contradiction by the existence of double-faced morality - official (formal), putting the principle of virtue in the first place and unofficial (but tolerated), allowing promiscuity" (Plzák, 1973, p. 22). Such double-faced morality not only undermines healthy emotional relations between partners but also does not allow erotic development and integration of the sexual sphere with the life ethos (Plzák, 1973, p. 22).

Ethical thought as related to the moralizing of sexuality has been divided among ethicists. One of the classifications worth mentioning was presented by Tadeusz Ślipko. He distinguishes 
absolutist ethics- to which he includes the ethics of natural law and personalistic ethics- from relativistic ethics, where he attributes humanistic orientation (secular and Christian orientation) and naturalistic orientation (including secular and Christian orientation). The author reduces the fundamental dividing line of anti-permissive, objective and absolute Christian ethics, from the relativistic, permissive liberal ethics (Ślipko, 2012, pp. 67-68, Ślipko, 2005, p. 284).

\section{Ethics, sexuality, norms, religion}

While the previous subchapter was aimed at considering the tension between morality and sex in the context of ethical thought, this subchapter's task is to show, through the writings of selected authors, the normative indications extrapolated from these texts on educational principles as seen through the sphere of sexuality. It should be noted that some views will be based on our comments. Such educational intervention is justified in so far as it is dictated by the necessity of a brief expression of thought.

Referring to social forces that moralized sex in antiquity, continuing to influence the modern era, it is worth pointing to the emergence of Christianity and its manner of drawing ethics from other ideologies. Apart from the religious aspects and oppressiveness resulting from Gnosticism, Stoic thought played an important role in this development. Uta Ranke-Heinemann emphasized, among other things, the significance of the Stoic school: "That increasingly rigorous assessment of sexual activity and the tendency to reduce it within the first two centuries after Christ was the result of the influences of the Stoics, the largest philosophical school of that time, from about $300 \mathrm{BC}$ to around 250 after Christ. The word "stoic" to this day means an attitude of indifference and dispassion" (Ranke-Heinemann, 2015, p. 17). It was the Stoics who, not only for antiquity, introduced undervaluation of the sexual sphere and physical relations between a man and a woman: "The suspicion aroused in the Stoics concerning striving for sensual enjoyment led, on the one hand, to admitting that sexual activity within marriage was of higher value than disordered life of the sexes; on the other hand, it led to neglecting marriage as being too far from the ideal of total abandonment of lust and passion" (Ranke-Heinemann, 2015, p. 17). Marriage as a joyful sexual relationship was crossed out at the beginning of the emergence of Christianity, which was not only burdened with Gnosticism, but also with the views of the Stoics: "[The] [M] arriage act remained connected with the concept of lust; it was impossible to be integrated; it was stigmatized with distrust concerning all the bodily pursuits aimed at experiencing pleasure. The idea that it should only be an act of procreation, that in any other case it should be related to a negative evaluation with the slogan "lust", not for example "love", left a particular mark on Christianity" (Ranke-Heinemann, 2015, p. 19). Quite heavy in its consequences was the conviction of Sextus who influenced Christian thought: "Who is a too passionate (ardentior $=$ hotter) a lover of his wife is an adulterer (...) Thomas Aquinas, second after Augustine as a pillar of sexual morality, repeated the above- mentioned idea: marriage is aimed at producing offspring, and therefore anyone who loves his wife too passionately, violates the well-being of marriage and can be called an adulterer" (Ranke-Heinemann, 2015, pp. 68-69). Concerning this view, it is worth mentioning the original thought expressed by Thomas Aquinas:

"... because pleasure in a good action is good, and in an evil action, evil; wherefore, as the marriage act is not evil in itself, neither will it be always a mortal sin to seek pleasure therein. Consequently the right answer to this question is that if pleasure be sought in such a way as to exclude the honesty of marriage, so that, to wit, it is not as a wife but as a woman that a man treats his wife, and that he is ready to use her in the same way if she were not his wife, it is a mortal sin; wherefore such a man is said to be too ardent a lover of his wife, because his ardour carries him away from the goods of marriage. If, however, he seek pleasure within the bounds of marriage, so that it would 
not be sought in another than his wife, it is a venial sin" (Thomas Aquinas, 2006, Supplement to the Third Part, q. 49, a. 6).

The separation of marriage from the possibility of joyful sex is an important influence on the formation of Christian sexual morality.

This problem is clearly evident in the views and attitudes expressed by Augustine of Hippo: "For Augustine, hostility to pleasure was even more important than the procreative goal of every marital act. (...) For Augustine, virginity ranked morally higher than marriage, and again any marriage without sexual relations was placed higher than marriage maintaining such relations. Giving up sexual life together, the spouses achieved a higher degree of moral development" (Ranke-Heinemann, 2015, p. 104). Sexuality in Christian, as well as Catholic thought, has been subjected to moral prohibitions for many centuries. To this day, there is a view that claims the procreative purpose to be the basis of the sexual relationship of spouses: "To put it simply, this position can be expressed employing a formula that is the reverse of the hedonistic-utilitarian view. The point is not to deny the presence and significant role of pleasure experienced in the structure of sexuality or to disregard it. However, the decisive factor shaping the proper reality of sexuality and defining the hierarchy of the importance of its constituent elements in sexuality is the procreative purpose. The deepest sense of sexuality is expressed in it. Sexuality directly and in the first place is directed towards creating and promoting life. In comparison with the procreative purpose, pleasure is considered as a secondary factor and is subordinated by its fundamental orientation, which constitutes its proper content and essence. Since the procreative purpose of sexuality deals with the objective perfection of human life, its position can be described as a perfectionistic, ethical, but not psychological" (Ślipko, 2012, p. 195).

Although Karol Wojtyła re-evaluated the sexuality of a person in Christian thought, he did not change the fundamental focus on the procreative purpose: "It cannot be presumed that sex drive, which has its purpose within man, the purpose that is determined, independent of will and self-determination of man, is something below the person and below love. The purpose of that drive is the existence of the species "Homo sapiens, its extension, procreatio; and the love of persons, of a man and a woman, is formed within this finality, in its bedrock, as it were; it is formed as if out of this material, which is provided by the drive" (Wojtyła, 2013, p. 36). Therefore, the sexual aspect of love between a woman and a man must be found in the drive to prolong the life of the species.

Dietrich von Hildebrand, on the other hand, recognizes marriage as the most suitable kind of interpersonal relationship capable of manifesting love: "Among all earthly communities, the "I-You" community gains the clearest shape in conjugal love, in which the beloved person is the object of thinking, feeling, thirst, longing and hope. In the order of created goods, the other person becomes the focal point of life. Someone who is filled with such love not only lives with another person but also lives for another person" (Hildebrand, 2017, p. 23). Karol Wojtyła also appreciates love as the most perfect human relation that receives its unique shape in spousal love:

\footnotetext{
"Spousal love is something other and something more than all the forms of love analysed so far, both from the perspective of the individual subject, from the perspective of the person who loves, and from the perspective of the inter-personal connection created by love. When spousal love enters in this inter-personal relation, then something other than friendship arises, namely the reciprocal self-giving of persons" (Wojtyła, 2013, pp. 78-79).
}

There is no denying that, for ethical thought, religious morality remains the reference point concerning sexuality, especially the views of the Catholic Church. In the Catechism of the 
Catholic Church, the procreative purpose determines the key, the essence of sexual relations. Love seems to be just an additive aiming to emphasize such purpose: "Fertility is a gift, the purpose of marriage because conjugal love by its nature tends to be fertile. The child does not come from the outside as added to the mutual love of the spouses; but emerges in the very center of this mutual gift of which it is the fruit and fulfillment. Therefore, the Church, "advocating for life", teaches that "every marriage act should remain open to the transmission of human life". Such teaching, repeatedly conducted by the Educational Office of the Church, has its basis in an unbreakable relationship established by God between the dual meaning of a marriage act: a unifying and procreational meaning. Such a relationship cannot be arbitrarily broken by a man" (Katechizm, 1994, p. 534, No. 2366).

The reasons for the polemics concerning setting specific rules for sexual relations in marriage seem to be provided by the Bible. Saint Paul in "The Letter to the Corinthians" entitles the spouses themselves with the opportunity to specify sexual relations and define their purpose: "As for the matters you have written about, it is good for a man not to connect with a woman. However, because of the danger of immorality, let everyone man have a wife and every woman have a husband. Let the husband give the duty to his wife, likewise the wife to her husband. Let not wife dispose of her own body, but her husband; neither does the husband possess his own body, but his wife only. Do not avoid one another, unless for a while, by mutual consent, so that to devote yourself to prayer; then you will come back to each other, for the sake of not being tempted by Satan due to the lack of temperance" (Pismo, 1990, p. 1290, 1 Cor 7: 1-6). Disposal of the body of a spouse can be considered as the principle of an exclusive relationship, without the possibility of interference by a third person or religion. The socialization of sexuality, even marital, can undermine the right to express one's eroticism. However, this problem will be addressed in the section on sexual self-education.

\section{Ethical eroticism and erotic self-education}

Before presenting the idea of a possible contemporary pattern of erotic self-education based on the view of "ethical eroticism", it is worth citing some significant opinions held in the past.

Jean Jacques Rousseau, in spite of his modern views on education, created quite a patriarchal image of sexual education. His work "Emil, or Education" addresses the development, the preparation of a woman - the wife intended for Emil. The author indicates first of all that "Sophy" is to be compliant. Compliance can be acknowledged as the basic characteristic feature that defines the relationship between Emil and Sophy. A woman is destined to give birth to children, to be a mother; however, a deeper knowledge of the world, including the study of philosophy, could harm her. First and foremost, she must have some practical knowledge. She must ground her outlook on the views of her husband. Moreover, in her family, she should have an appropriate upbringing to ensure that she will be: natural, good, honest, insightful, kind, intelligent and free from hypocrisy in her behavior. Interestingly enough, there is a belief that she should be sent away from home at the age of around 15. Being in society is not only a way to find a husband but also provides the training necessary to be a house-wife. At home, however, she cannot behave like a "smart woman", but must be a suitable companion for her husband (Rousseau, 2011, pp. 285-370).

Ethical eroticism, which is supposed to be the guiding principle for erotic self-education, cannot be based on the patriarchal system, following the contemporary ethical standard (Hartman, 2015, pp. 24-26), because it should assume a relationship between two partners (Grzybek \& Bielak 2015, pp. 79-90). In the theory of "Development ethics", the definition of ethics is related to three aspects: firstly, ethics as a philosophical discipline, knowledge of the art of life, and secondly, life ethos, i.e. personal ethical standards. The third approach opposes morality as an external regulatory system that exerts pressure on the individual to perform a particular behavior pattern (Grzybek, 2014, pp. 71-72). The approach of "ethical eroticism" 
refers to the opposition to social morality, including sexual development of each individual's ethical standards with relation to sexuality (Grzybek, 2020, pp. 45-49).

"Ethical eroticism" can be understood as integration, that is, the development of cognitive and volitional capacities. Eroticism is then ethical when it approaches the development of cognitive and volitional skills. The moral dimension of eroticism is "dressed up" in the impact of the morality of pressure. The morality of pressure rules eroticism through prohibitions, orders, and commandments. "Ethical eroticism" contributes to the development of an ethical personality. The basic references are not norms - orders, prohibitions, commandments, but values, above all the following basic ones: freedom, wisdom, love, happiness, the dignity of a person. Eroticism is a quality that can be well or badly used; it can value or destroy, depending on the reference to values, but not norms. Wisdom justifies the choice, freedom creates the space of choice, love constitutes the object of eroticism, happiness confirms its quality, dignity of a person, and his/her integration (Grzybek, 2015, pp. 11-17; Grzybek \& Tobiczyk, 2018, pp. 82-91).

Being based on "ethical eroticism", erotic self-education should mean the integration of one's sexuality with one's life ethos (understood as a specific way of being, which is not determined by morality of pressure, but by ethically justified principles of life activity and goals, Grzybek, 2014, pp. 72, 84). The ethical reference for self-education based on ethical eroticism should not be morality as such, but human rights, as well as respect for the dignity and integrity of another person. Morality, being the main component of socialization, absorbs not only positive but also negative elements. Maturity, including ethical personality, should allow acceptance of what is positive and rejection of what is negative in sexual morality based on socialization pressure. According to assumptions of Development Ethics, an ethical personality means "such a state of development of the cognitive and volitional powers of man, which allows a person to persistently strive for one's moral perfection. From the beginning of existence, a man possesses his moral being, and his ethical personality is created through his work, cognitive and volitional efforts" (Grzybek, 2013, pp. 102-103). Thus, sexual morality is above all the nature of external pressure, while "ethical eroticism" is the conscious attitude of the subject of activity.

The theory of Development Ethics emphasizes the subjectivity of the individual concerning social unity (the social wholeness). Socially specified sexuality puts pressure on the behavior of the individual, while "ethical eroticism" together with the concept of erotic self-education provides moral arguments for the right to development, including the sphere of sexuality, and the possibility of self-determination concerning the directions of self-realization (Grzybek, 2020, pp. 186-200; Grzybek \& Siwek, 2020, pp. 137-141). In this context, it should be reasonable to refer to the autonomy of the moral subject, where the social consequences of an action depend on the level of the subject's responsibility (Gluchman, 2018, pp. i-xxvii; Kalajtzidis, 2017, pp. 37-49).

\section{Conclusions}

The above-mentioned, however, does not mean the rejection of social morality regarding sexuality, which is culturally diverse today; rather, it emphasizes the personal concept of erotic development. In developing an individual concept of erotic development, one can address the category of existence aesthetics (Grzybek, 2020, pp. 201-206; Foucault, 1978, pp. 378-379). Moreover, sexuality means the approach that is of the character of socially and culturally defined norms, while eroticism appears to be a kind of space for development by an individual and, in this, it is the opposite of sexuality. Due to the generally accepted terminology in ethical thought, one should refrain from using the term erotic ethics, but rather choose erotic selfeducation, which emphasizes its unique personal dimension. 
When considering the ethical dimension of erotic self-education, two aspects should be taken into account: 1) moral interest in sex, which can adopt a negative meaning, and 2) "ethical eroticism" which in terms of Development Ethics means positive integration of sexuality with life ethos. Such an approach to sexual ethics is based on the right of a person to express his/her eroticism, guided by the aesthetics of existence, rather than on the social aspect.

Sexual ethics based on the concept of Development Ethics emphasizes above all the right to be guided by individual ethical standards, which should not violate the law, nor the freedom and dignity of others (Grzybek, 2014, p. 68).

\section{References}

BATAILlE, G. (2008): Historia erotyzmu [L'Histoire de l'érotisme], trans. I. Kania. Warszawa: Aletheia.

BAUMAN, Z. (2006): Liquid fear. Cambridge: Polity Press.

BAUMAN, Z. (2010): Liquid times: Living in an age of uncertainty. Cambridge: Polity Press. FOUCAULT, M. (1978): The history of sexuality, trans. R. Hurley. New York: Random House. FROMM, E. (1999): Love, sexuality and matriarchy: About gender, ed. R. Funk. New York: Fromm International.

GLUCHMAN, V. (2018): Ethics of social consequences: The past and the present. In: V. Gluchman (ed.): Ethics of social consequences: Philosophical, applied and professional challenges. Newcastle: Cambridge Scholars Publishing, pp. i-xxvii.

GRZYBEK, G. (2010): Etyka rozwoju a wychowanie [Development ethics and upbringing]. Rzeszów: UR.

GRZYBEK, G. (2013): Etyka rozwoju a pedagogika opiekuńcza [Development ethics and pedagogy of care]. Rzeszów: UR.

GRZYBEK, G. (2014): Etos życia. Wychowanie do matżeństwa w założeniach etyki rozwoju [The ethos of life: Marriage education according to the principles of development ethics]. Rzeszów: UR.

GRZYBEK, G. (2016): Etyka zawodowa jako subdyscyplina naukowa [Professional ethics as a scientific subdiscipline]. Rzeszów: UR.

GRZYBEK, G. (2020): Etos i eros. Etyka rozwoju wobec seksualności a samowychowanie. [Ethos and eros: Development ethics towards sexuality in relation to self-education]. Rzeszów: UR.

GRZYBEK, G. \& BIELAK, A. (2015): The ethics of the teacher and the debate about gender. In: Ethics \& Bioethics (in Central Europe), 5(1-2), pp. 79-90.

GRZYBEK, G. (2015): Ethics, education and the gender dispute. In: Zbirnyk naukovykh prac Kamianets-Podilskoho Natsionalnoho Universytetu imeni Ivana Ohiyenka. Seria pedahohichna, Vypusk 18 (1) [Collection of scientific papers Kamianets-Podilskyi National Ivan Ohiienko University. Pedagogical series]. Kamianets-Podilskyi: Medobori, pp. 11-17.

GRZYBEK, G. \& SIWEK, SZ. (2020), Satysfakcja seksualna, prawa człowieka, samowychowanie erotyczne. Refleksja etyczna. [Sexual satisfaction, human rights and erotic self-education]. In: Scientific Bulletin of Flight Academy. Section: Pedagogical Sciences, 7, pp. 137-141.

GRZYBEK, G. \& TOBICZYK, P. (2018): Sexual ethics of Catholic religion versus development ethics. In: Zbirnyk naukovykh prac Kamianets-Podilskoho Natsionalnoho Universytetu imeni Ivana Ohiyenka. Seria pedahohichna, Vypusk 3 [Collection of Scientific papers Kamianets-Podilskyi National Ivan Ohiienko University. Pedagogical series]. Kamianets-Podilskyi: Medobori, pp. 82-91.

HARTMAN, J. (2015): Etyka! Poradnik dla grzeszników [Ethics: Manual for Sinners]. Warszawa: Agora SA. 
HILDEBRAND, D. v. (2017): Matzeństwo [Marriage], trans. J. Kubaszczyk. Poznań: „W drodze".

KALAJTZIDIS, J. (2017): Moral agency in the ethics of social consequences and its comparison in the context of consequentialism. In: V. Gluchman (ed.): Ethical Thinking Past \& Present (ETPP 2017/18). Human being in contemporary ethics. Prešov: Filozofická fakulta Prešovskej univerzity, pp. 37-49.

KATECHIZM KOŚCIOŁA KATOLICKIEGO [Catechism of the Catholic Church]. Poznań \& Warszawa: PALLOTINUM, 1994.

OSHO (2003): Sex matters: From sex to superconsciousness. New York: St. Martin's Press.

PISMO ŚWIETE Starego i Nowego Testamentu w przekładzie z języków oryginalnych. Poznań \& Warszawa: PALLOTINUM, 1990.

PLZÁK, M. (1973): Strategia i taktyka w miłości [The strategy and Tactics of Love], trans. T. Siemek. Warszawa: Wiedza Powszechna.

RANKE-HEINEMANN, U. (2015): Seks odwieczny problem Kościoła [Sex as Eternal Problem of the Church]. Warszawa: RM.

ROUSSEAU, J. J. (2011): Emile, or on education, trans. B. Foxley. London \& Toronto: J.M. Dent and Sons.

SINGER, P. (1999): Practical ethics. Cambridge: Cambridge University Press.

ŚLIPKO T. (2012): Przedmatżeńska etyka seksualna [Pre-marriage sexual ethics]. Kraków: Petrus.

ŚLIPKO, T. (2005): Zarys etyki szczegółowej. T. 1: Etyka osobowa [The Outline of Specific Ethics. V. 1. Personal Ethics]. Kraków: Wyd. WAM.

THOMAS AQUINAS (2006). The Summa Theologica, trans. Fathers of the English Dominican Province. [online] [Retrieved April 11, 2020] Available at: http://www.documentacatholicaomnia.eu/03d/1225-1274,_Thomas_Aquinas,_Summa_Theol ogiae_\%5B1\%5D,_EN.pdf

WOJTYŁA, K. (2013): Love and responsibility, trans. G. Ignatik. Boston: Pauline Books. 